\author{
International \\ Journal of \\ 府ducation \\ DOI : $10.15740 / \mathrm{HAS} / \mathrm{IJPE} / 8.2 / 87-90$ \\ e ISSN-0976-7924 $\mathbf{\square}$ Visit us : www.researchjournal.co.in \\ Research Paper
}

Volume 8 | Issue 2 | October, 2015 | 87-90

\title{
Effect of yoga on physical fitness of nurses
}

\section{SANTOSHI SAULKAR}

Received : 15.07.2015; Revised : 20.08.2015; Accepted : 22.09.2015

Author for correspondence

SANTOSHI SAULKAR

Vasantrao Naik College of

Agricultural Biotechnology (DR.

P.D.K.V.), YAVATMAL (M.S.) INDIA

\section{-ABSTRACT}

The purpose of the study was to examine physical fitness of nurse's. The present study was conducted on 50 nurses from private Hospitals, Amravati city, respectively. Nurse age ranging from 30 to 40 year The randomly selected. The necessary data were collected by various instruments. On the basis of result, it is reveled that should beneficial on selected physical fitness components of different age group ' $F$ ' test was applied for analyzing the data. Positive effect among the Nurses was observe after yoga training.

- KEY WORDS : Asana, Pranayam, B.M.I., Fat cardio-vascular capacity, Agility, Strength

- HOW TO CITE THIS PAPER : Saulkar, Santoshi (2015). Effect of yoga on physical fitness of nurses. Internat. J. Phy. Edu., 8 (2) : 87-90. 